\title{
Justification of ICT Expenditure: Input and Outputs
}

\author{
Conference discussion group paper
}

Jacques Bulchand (Chair), Omponye Kereteletswe, Antonio Castro,

Maipelo Molebatsi (Rapporteur), and Marcos Maedza

University of Las Palmas de Gran Canaria, Spain, Office of the President (OP), Botswana

Centre Algoritmi, Portugal, Ministry of Transport and Communications - DIT, Botswana Ministry of Education and Skills Development - IT Unit, Botswana, Ministry of Education and

Skills Development - Central Region, Botswana

\section{Challenges in Justifying the ICT Expenditure}

The discussion commenced by discussing matters affecting the decisions to spend on ICT by government. Dr Kereteletswe indicated that we need to be in a position to justify to the Ministry of Finance and Development Planning the ICT expenditure. The chairman further added that currently the entire world is recovering from the economic melt-down hence this factor is used to justify the ICT budget cuts. $\mathrm{Mr}$ Balebetse supported the matter adding that we need to question why ICT is always targeted when budget cuts are made. This tendency shows that the decision makers do not have appreciation of the value-addedness or benefits derived from investing in ICT. The chairman added that this is due to the fact that the benefits from ICT are not immediate as compared to other investments or projects like roads construction, building schools. All the mentioned projects, upon completion one already derives satisfaction that they are having value for the money generated in their development. Hence this results in further challenges to justify the ICT expenditure.

The chairman lamented that in most cases when ICT budgets are presented, only $50 \%$ of the entire expenditure is requested and this normally covers procurement costs, development costs excluding maintenance costs. With this elimination of some essential services required by ICT departments, it means there will be a need to make further requests to cover the remaining costs after completing the implementation or development of projects for which the budget was intended. This 'coming-back' for more habit is the one that makes decision makers hesitant to release more funds as at this point they are expecting benefits and not more spending. This shows that there is a tendency of requesting less than what we need. Ms Molebatsi asked why now as IT Managers since we know that on top of the implementation /development costs there will be additional costs of maintenance not cover all costs upon request for funding. In answering, Dr Kereteletswe responded that this is due to poor planning by the entire system. He added that if the budget is not results based, it is definitely going to fail. Maintenance costs when included in the budget, the decision makers believe the costing is exaggerated and unrealistic giving an example with the current eGovernment Project. The cost is estimated at $€ 102$ million but it will take a few years before the real benefits are experienced. 
Mr Maedza commented that much attention is not paid to joint planning. We have one government but when we plan, this is done in silos. Dr Kereteletswe added that a holistic view of the entire government ICT demand is ignored hence challenges to make a justification holistically. Ministries make their own demands and plan in isolation.

Mr Castro highlighted that it is always difficult to justify investment especially for ICT because it is very difficult to measure it. The chairman supported the point adding that there is a huge difference in ICT measurements as compared to other projects like building a road and using it upon completion. We need to know how to measure the Return on Investment (ROI) for ICT. Dr Kereteletswe added that the main challenge is that the politicians need immediate results. He added that there are two important factors to be considered namely

- Cost effectiveness

- Accrued benefits

Dr Kereteletswe continued that it is essential to always plan strategically as per the balance score card where it states that you require the right human resources to drive the systems to get your desired results. The chairman said the Information system is made up of 3 components namely

- Organisation

- Technology

- People

But within our organizations, the main focus is on technology, forgetting that the people need to be trained to be able to use the technology to improve the organizational performance. Mr Castro added that when we invest in Information systems we need to see that as an opportunity to start developing our human resource. (Refer to the below diagram (Information system)

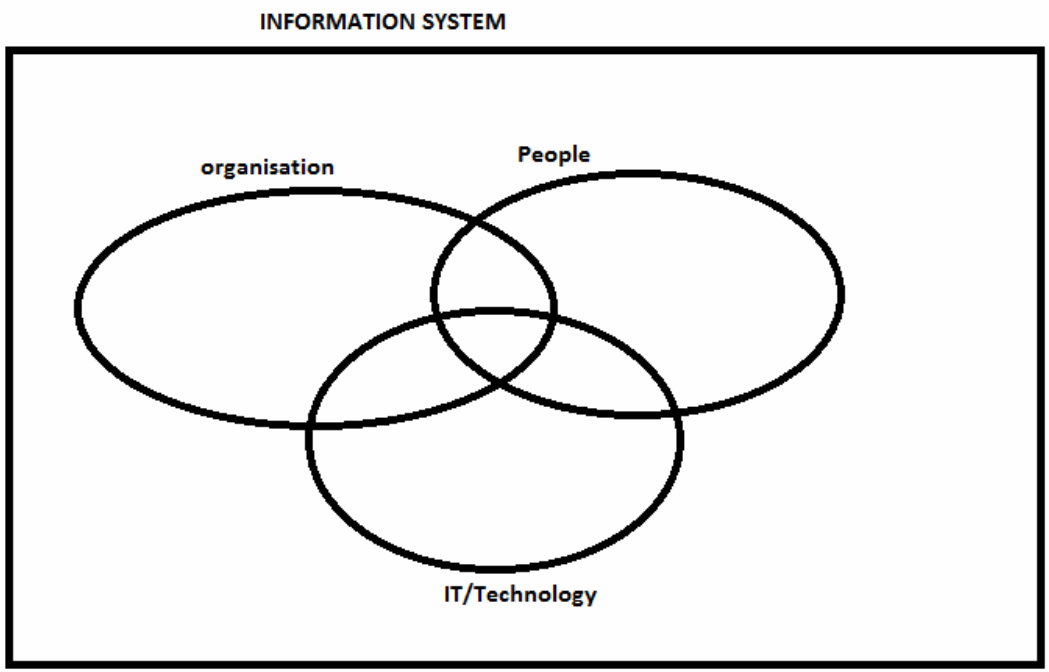


The chairman threw a question that 'Can we archive innovation without IT?' In response, the group responded in affirmation. He said that in the past 15 years, innovation has been IT driven but innovation can be achieved without using IT. This can be a challenge because people are resistant to change. Dr Kereteletswe lamented that the politicians are interested in input and output alignment but for IT real benefits can take up to 7 years hence not a priority to be added on their 5year development roadmaps (manifestos). The chairman gave an example that there is currently a proposal in Spain to have a fibre optical cable build in each road construction. This initiative is cost effective. Another advantage of IT is that it eases access to the remote areas within the country according to Mr Maedza. Mr Castro added that we need to develop infrastructure first and this will allow service delivery at the end.

Ms. Molebatsi added that currently in Botswana, government is investing more in ICT in secondary schools leaving out the primary schools. The primary school students are only given refurbished computers as a way of introducing them to information technology but this is always having challenge of untrained teachers. In his response Dr Kereteletswe said that our leaders need to have a change of mindsets and attitudes because it would be ideal to introduce the students to ICTs at a tender age and not when they are at secondary schools. Mr Balebetse responded that this is normally due to lack of funding. There are more primary schools in the country compared to secondary schools. The chairman added that other alternative can be taken by parents to buy computers for their children and connect internet in their homes as majority of them can afford it.

Mr. Balebetse added that at primary schools the other main challenge is power supply. Most of the primary schools in the country do not have electricity hence making it a challenge to operate ICT infrastructure. Currently the government is trying to come with ways of addressing this challenge by piloting with the use of solar power to assist the Community kitsong centres (internet access points in villages) and primary schools giving an example of the Kaudwane village in the Kweneng region. The other main challenge with bringing primary school ICT infrastructure to the same level as secondary schools is due to lack of proper coordination of the project since it is made up of 3 main stakeholders. These are Ministry of Education and Skills Development (driving the education ICT policy), Ministry of Local Government (responsible for bringing infrastructure at primary schools) and Ministry of Transport and Communications (responsible for providing ICT infrastructure to government institutions).

Mr. Balebetse continued saying that his ministry (Ministry of Transport and Communications) is taking advantage of the rural electrification project spearheaded by Ministry of Minerals,Energy and Water Resources.

Mr. Balebetse added that the other challenge is the high tax rates. Currently the tax makes up $30 \%$ of the purchase price hence making it expensive to procure ICT equipment especially that it is always sourced from outside the country. Dr Kereteletswe responded that if there is buy-in from the decision makers, ICT equipment could be exempted from taxes or reduced to make them affordable to government. Customs duty is at $20 \%$ and the VAT at $12 \%$. Another alternative is to have the equipment entering the country at the Martin's Drift free-tax border post. 


\section{Solutions}

Be realistic with costs of ICT projects; Refrain from under-budgeting

Sensitize / train our politicians about costs for ICTs since they have long term benefits

Benchmarking and best practices: Since Africa is slightly behind in technology countries can benchmark with more developed countries to copy ideas and plans

When planning, we need to link outputs to results especially when presenting to politicians

Planning together of all stakeholders (politicians and public service) for long term eg Vision 2016, National Development Plans.

Link ICT costs to outputs that accrue as a result of the use if ICTs

Give ICT technicians training in strategic management to improve their management skills; IT officers to be part of organizational management

Phased implementation of projects; 